be tested. Chest radiography should be limited to employees with relevant respiratory symptoms; this would result in considerable financial saving and a reduction in avoidable radiation.

I thank the nursing staff of this department for their help and cooperation with this study.

Society. Control and prevention of tuberculosis in Britain: an updated code of Practice BMF 1990;300:995-9.

2 Cockcroft A, Chaturvedi N, Waldron HA. Tuberculosis in Britain. BMg 1990;300:1723-4.

3 Medical Research Council Cardiothoracic Epidemiology Group. National survey of notifications of tuberculosis in England and Wales in 1988. Thorax 1992;47:770-5.

4 Lunn JA, Mayho V. Incidence of pulmonary tuberculosis by occupation of hospital employees in the National Health Service in England and Wales 1980-4. f Soc Occup Med 1989;39:30-2.

(Accepted 2 February 1993)

\section{Litter and medical waste on bathing beaches in England and Wales}

\author{
Robin Philipp, Kathy Pond, Gareth Rees
}

WHO Collaborating Centre for Environmental Health Promotion and Ecology, Department of Epidemiology and Public Health Medicine, University of Bristol, Bristol BS8 2PR

Robin Philipp, director

\section{Farnborough College of} Technology, Farnborough Kathy Pond, national coordinator, Norwich Union

Coastwatch UK

Gareth Rees, head, department of science and environmental technology

Correspondence to: Dr Philipp.

$B M F$ 1993;306:1042 risks.

\section{Methods and results}

Medical wastes have appeared on holiday beaches, ${ }^{1}$ and gastrointestinal symptoms have been associated with the aesthetic appearance of bathing water and beaches. ${ }^{2}$ In 1990 the House of Commons reported that the aesthetic quality of recreational waters is "becoming increasingly important as the public become more aware of, and sensitive to, the risks," ${ }^{3}$ and in 1991 the World Health Organisation and the United Nations Environment Programme reported that "the aesthetic and hygienic quality of beaches deserves immediate attention." ${ }_{4}$ This study looked for evidence of aesthetic

In October 1991, for Norwich Union's Coastwatch UK project, the coastline of Britain was divided into 5 kilometre blocks and surveyed during a two week period. At low tide, volunteers completed a questionnaire for each $0.5 \mathrm{~km}$ unit of their allocated block. Priority was given to accessible bathing beaches, and there was easy access to $69 \%$ of the coastline units surveyed. Written instructions and telephone briefings were provided, and 10 regional coordinators trained in coastline management issues were available for local advice. The volunteers recorded the presence of specified litter items in the area between high and low tides and counted the number of beverage cans, plastic packing straps and rings, containers of potentially dangerous materials such as chemicals and gas cylinders, plastic bottles, and medical waste. As the size of beach area above high tide level could vary considerably among coastline units, and because litter counts above high tide level vary with the daily population density of beach users, litter counts were restricted to this intertidal area. As part of unpublished Coastwatch Europe studies the method had been previously found reliable in Ireland. In this study, it was not possible-with staffing constraints and because the volunteers could choose which day to do their fieldwork - to validate the findings in a sample of locations before the next high tide. Internal crosschecks were undertaken and confirmed consistency of the data.

Of 7000 distributed questionnaires, $4226(60 \%)$ were completed and returned. Principal reasons for non-response were travel difficulties, poor weather, and illness. More than $15 \%$ of the British coastline $(2113 \mathrm{~km})$ was surveyed. The table shows how many coastline units in England and Wales and in the south western region were found to have different items of
Litter on beaches in England and Wales summer 1991

\begin{tabular}{|c|c|c|}
\hline & $\begin{array}{l}\text { No }(\%) \text { of units } \\
\text { in England and } \\
\text { Wales }(n=3317)\end{array}$ & $\begin{array}{l}\text { No }(\%) \text { units in } \\
\text { south western } \\
\text { England }(n=667)\end{array}$ \\
\hline Beverage cans & $1758(53)$ & $313(47)$ \\
\hline Plastic bottles & $1692(51)$ & $320(48)$ \\
\hline Paper or cardboard & $1625(49)$ & $313(47)$ \\
\hline Unspecified plastics & $1625(49)$ & $307(46)$ \\
\hline Plastic fishing gear & $1294(39)$ & $240(36)$ \\
\hline Polystyrene foam & $1095(33)$ & $227(34)$ \\
\hline Clothing items & $1095(33)$ & $213(32)$ \\
\hline Glass bottles or fragments & $929(28)$ & $147(22)$ \\
\hline Plastic straps or beer can holders & $929(28)$ & $180(27)$ \\
\hline Mammalian faeces & $464(14)$ & $60(9)$ \\
\hline Sanitary materials & $464(14)$ & $92(14)$ \\
\hline Large metal objects $\dagger$ & 365 (11) & $47(7)$ \\
\hline Food or fish waste & 365 (11) & $53(8)$ \\
\hline \multicolumn{3}{|l|}{ Containers of potentially hazardous } \\
\hline materialsł & $332(10)$ & $60(9)$ \\
\hline Tar & $265(8)$ & $73(11)$ \\
\hline \multicolumn{3}{|l|}{ Household refuse in plastic bags or } \\
\hline Household furniture & $\begin{array}{l}232(7) \\
199(6)\end{array}$ & $\begin{array}{l}47(7) \\
33(5)\end{array}$ \\
\hline Oil or petrol & $166(5)$ & $47(7)$ \\
\hline Medical waste $\oint$ & $133(4)$ & $13(2)$ \\
\hline
\end{tabular}

$\star^{\star} 0.5 \mathrm{~km}$ of coastline.

†For example, abandoned vehicles, machinery, girders.

$\ddagger$ For example, chemicals, gas cylinders.

@Materials generated as a result of patient diagnosis, treatment, or immunisation.

litter. Percentages were generally similar in the two areas.

Of 306 items of medical waste identified on the coastline of England and Wales (one per $5.4 \mathrm{~km}$ of surveyed coastline), 202 were "unspecified," and there were 42 syringes, 19 asthma inhalers, seven gloves, two intravenous drip bags, one colostomy bag, and 33 miscellaneous items such as cotton buds, dressings, plasters, packaging, and specimen sample bottles. The 35 items of medical waste in the south western region of England comprised 21 unspecified items, 11 syringes, two phials, and one asthma inhaler.

\section{Comment}

An important theme of the 1990 Environmental Protection Act is "control of waste from the cradle to the grave" and local authorities are striving hard to control waste along the coastline. Nevertheless, if our personal and collective efforts for litter and pollution control are not improved, the findings reported here suggest that at least in south western England, a very popular area for summer tourists, there could be considerable consequences from adhering to the $B M F$ s recent advice that "if a beach looks filthy, don't swim in the sea."

1 Godlee F, Walker A. Importance of a healthy environment. BM7 1991;303: $1124-6$

2 University of Surrey. The public health implications of sewage pollution of bathing water. Guildford: Robens Institute of Industrial and Environmental Safety, 1987:25.

3 House of Commons. Environment Committee. Fourh report. Pollution of beaches. Vol 1. London: HMSO, 1990.

4 United Nations Environment Programme, World Health Organisation. Assessment of the state of pollution of the Mediterranean Sea by pathogenic organisms. Athens: UNEP, 1991:34. (UNEP(OCA)/MED WG.25/Inf.7.)

5 Walker A. Swimming - the hazards of taking a dip. BMf 1992;304:242-5.

(Accepted 28 fanuary 1993) 